\title{
ANALISIS KESTABILAN MODEL SEAK PADA PENYEBARAN PENYAKIT FILARIASIS
}

\author{
A. Wahyudin 1 , R. Ratianingsih², dan N. Nacong ${ }^{3}$ \\ 1,2,3Program Studi Matematika Jurusan Matematika FMIPA Universitas Tadulako \\ Jalan Soekarno-Hatta Km. 09 Tondo, Palu 94118, Indonesia \\ 1agustiraniwahyudin26@gmail.com.2ratianingsih@yahoo.com.3nasrianacong@gmail.com
}

\begin{abstract}
Filariasis or elephantiasis is a disease caused by infection of filarial worms. This research studies the spread model of elephantiasis disease that is influenced by the birth rate, the natural mortality rate, the transfer rate of susceptible exposed mosquito to the exposure due to the interaction between susceptible mosquito and infected human population, the transfer rate of exposed mosquito to the infected, the transfer rate of vulnerable human to the exposure human populations as a result of the mosquito and susceptible human intraction, the transfer rate of exposed human population to the infected human population, and the transfer rate of the infected human population to chronically human population. Filariasis disease spread model is built in form of Susceptible - Exposed - Acute Kronic (Seak). The model is a nonlinear differential equations system of dependent variables that are the vulnerable, exposed, infected human populations, and chronic and vulnerable exposed, and infected mosquito population. The model has a critical point namely $T_{1}=\left(\frac{A_{v}}{\mu_{1}}, 0,0, \frac{A_{m}}{\mu_{2}}, 0,0,0\right)$ that represents the free-disease conditions and the critical point $T_{2}=\left(S_{v}^{*}, E_{v}^{*}, I_{v}^{*}, S_{m}^{*}, E_{m}^{*}, A_{m}^{*}, K_{m}^{*}\right)$ that represents an endemic condition. The critical points is analyzed using the method of linearized stability and Routh Hurwitz criteria. $T_{1}$ is the vertical point stable while $T_{2}$ is unstable. The result indicates that the free- disease condition is settled, while the endemic will be left in a long time period. It could also be interpreted that the endemic have a chance be overcome.
\end{abstract}

Keywords : Filariasis, Linearization Method, Model SEAK, Routh Hurwitz Criterion

\section{ABSTRAK}

Filariasis atau elephantiasis adalah penyakit yang disebabkan oleh infeksi cacing filaria. Pada penelitian ini dikaji model penyebaran penyakit kaki gajah yang dipengaruhi oleh parameter laju kelahiran, laju kematian alami, laju perpindahan populasi nyamuk rentan ke populasi nyamuk exposed akibat interaksi antara populasi nyamuk rentan dengan populasi manusia terinfeksi, laju perpindahan populasi nyamuk dalam masa exposed ke populasi nyamuk terinfeksi, laju perpindahan populasi manusia rentan ke populasi manusia dalam masa exposed akibat interaksi antara populasi nyamuk terinfeksi dengan populasi manusia rentan, laju perpindahan populasi manusia dalam masa exposed ke populasi manusia terinfeksi, dan laju perpindahan populasi manusia terinfeksi ke populasi manusia kronis. Model penyebaran penyakit filariasis dibangun dalam model Susceptible - Exposed - Acute Kronic (SEAK). Model tersebut berupa sistem persamaan diferensial tak linier dari variabel-variabel terikat yang 
merepresentasikan pembagian populasi manusia atas sub populasi manusia rentan, exposed, terinfeksi, dan kronis dan populasi nyamuk atas sub populasi nyamukrentan, exposed, dan terinfeksi. Model memiliki titik kritis $T_{1}=$ $\left(\frac{A_{v}}{\mu_{1}}, 0,0, \frac{A_{m}}{\mu_{2}}, 0,0,0\right)$ yang menggambarkan kondisi bebas penyakit dan titik kritis $T_{2}=\left(S_{v}^{*}, E_{v}^{*}, I_{v}^{*}, S_{m}^{*}, E_{m}^{*}, A_{m}^{*}, K_{m}^{*}\right)$ yang menggambarkan kondisi endemik. Kedua titik kritis tersebut dianalisis kestabilannya menggunakan metoda linearisasi dan kriteria Routh hurwitz, dimana $T_{1}$ adalah stabil sedangkan $T_{2}$ adalah tidak stabil. Hal ini menunjukkan bahwa kondisi bebas penyakit bersifat menetap sedangkan kondisi endemik dalam waktu yang lama akan ditinggalkan. Dapat diinterprestasikan pula bahwa kondisi endemik masih bisa diupayakan untuk diatasi.

Kata Kunci : Filariasis, Metoda Linearisasi, Model SEAK, Kriteria Routh Hurwitz

\section{PENDAHULUAN}

Filariasis (penyakit kaki gajah) atau juga dikenal dengan elephantiasis adalah penyakit menular dan menahun yang disebabkan oleh infeksi cacing filaria yang ditularkan melalui perantara gigitan berbagai spesies nyamuk. Terdapat tiga spesies cacing penyebab Filariasis yaitu: Wuchereria bancroft; Brugia malayi; Brugia timori. Semua spesies tersebut terdapat di Indonesia, namun lebih dari $70 \%$ kasus filariasis di Indonesia disebabkan oleh Brugia malayi. (Depkes, 2009)

Penyakit filariasis bersifat menahun (kronis) dan jarang menimbulkan kematian pada penderitanya. Namun, bila penderita tidak mendapatkan pengobatan, penyakit ini dapat menimbulkan cacat menetap pada bagian yang mengalami pembengkakan (seperti: kaki, lengan dan alat kelamin) baik pada penderita laki-laki maupun perempuan. Berdasarkan laporan dari kabupaten/kota, jumlah kasus kronis filariasis yang dilaporkan sampai tahun 2009 sudah sebanyak 11.914 kasus. (Depkes, 2009).

Penelitian ini meninjau penyebaran penyakit filariasis dengan menambahkan sub-populasi exposed mengingat sebelum dikategorikan sebagai populasi terinfeksi, manusia yang digigit nyamuk yang mengadung filaria akan mengalami masa exposed selama 14 hari. Tahap exposed ini terjadi pada kedua sub-populasi baik manusia maupun nyamuk. Penambahan sub-populasi tersebut menjadikan model SAK direvisi menjadi model SEAK. Berdasarkan hal tersebut, penulis tertarik untuk meneliti bagaimana menganalisa revisi tersebut dalam mengkaji secara matematis penyebaran penyakit Filariasis. Dalam menentukan kestabilan model SEAK digunakan metode Routh- Hurwitz. Metode ini tidak menghitung akar-akar karakteristik secara langsung, namun memberikan kriteria kestabilan yang di identifikasi melalui koefisien persamaan karakteristik. Setelah kriteria kestabilan didapatkan maka selanjutnya akan dilakukan simulasi.

\section{PROSEDUR PENELITIAN}

1. Memulai penelitian.

2. Mengkaji Literatur.

3. Mengambil data dari artikel dan publikasi ilmiah.

4. Membangun model penyebaran penyakit Filariasis. Model dibangun berdasarkan informasiinformasi yang telah diperoleh dari literatur. 
5. Mencari titik kesetimbangan model penyakit Filariasis.

6. Menganalisa kestabilan model penyebaran penyakit Filariasis.

7. Melakukan simulasi kestabilan dari persamaan model penyebaran penyakit Filariasis.

8. Menyimpulkan hasil penelitian.

9. Selesai.

\section{HASIL DAN PEMBAHASAN}

\subsection{Model Matematika Penyakit Filariasis Pada Manusia}

Pada Gambar 1 memperlihatkan alur masuk dan keluarnya individu dalam populasi. Arah panah masuk menunjukkan masuknya individu ke dalam subpopulasi dan arah panah keluar menunjukkan keluarnya individu dari subpopulasi. Adapun garis lurus menunjukkan adanya interaksi antar subpopulasi.

Proses penyebaran filariasis dinyatakan sebagai suatu persamaan diferensial nonlinear yang disebut model epidemi. $S_{v}$ adalah populasi nyamuk yang rentan (Susceptible Vector), $E_{v}$ adalah populasinyamuk pada masa exposed(Exposed Vector), $I_{v}$ adalah populasi nyamuk yang terinfeksi dan siap menginfeksi (Infected Vector) ,Sm adalah populasi manusia yang rentan terhadap penyakit (Susceptible Human), $E_{m}$ adalah populasi manusia exposed (Exposed Human), $A_{m}$ adalah populasi manusia yang terinfeksi penya kit (Acute Human), $K_{m}$ adalah populasi manusia yang kronis terhadap penyakit (Chronic Human). Skema pertumbuhan, kematian, dan interaksi dari masing-masing populasi yang menggambarkan penyebaran penyakit filariasis pada manusia yang disebabkan oleh cacing filaria ditampilkan pada Gambar 1.

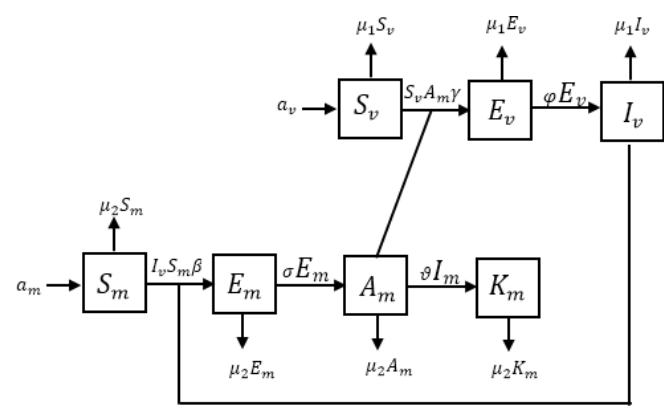

Gambar 1 : Alur penyebaran penyakit filariasis pada manusia 
Laju kelahiran nyamuk, berpindah ke populasi nyamuk yang rentan terhadap penyakit berpindah ke populasi dalam masa exposed setelah adanya interaksi dari manusia yang dalam masa exposed dan manusia yang terinfeksi sebesar $S_{v} A_{m} \gamma$, dengan masa exposed selama 14 hari dan berpidah ke populasi nyamuk yang terinfeksi sebesar $\varphi E_{v}$, adanya peluang interaksi nyamuk yang dalam masa exposed berinteraksi dengan manusia yang dalam masa exposed dan manusia yang kronis tanpa ada pengaruhnya sebelum berpindah ke populasi nyamuk yang terinfeksi, kemudian adanya interaksi nyamuk yang terinfeksi ke populasi manusia yang rentan sehingga populasi manusia berpindah ke populasi manusia yang dalam masa exposed, dalam waktu 8- 12 bulan dalam masa exposed populasi manusia berpindah ke populasi manusia yang terinfeksi, dan apabila populasi manusia yang terinfeksi tidak diobati akan berpindah ke populasi manusia yang terinfeksi kronis.

Dari diagram kompartemen pada Gambar 1 dibangun model matematika penyebaran penyakit filariasis, yang dapat dituliskan ke dalam sistem persamaan diferensial (SPD) sebagai berikut:

$$
\begin{aligned}
& \frac{d S_{v}}{d t}=a_{v}-\gamma S_{v} A_{m}-\mu_{1} S_{v} \\
& \frac{d E_{v}}{d t}=\gamma S_{v} A_{m}-\varphi E_{v}-\mu_{1} E_{v} \\
& \frac{d I_{v}}{d t}=\varphi E_{v}-\mu_{1} I_{v} \\
& \frac{d S_{m}}{d t}=a_{m}-\mu_{2} S_{m}-\beta S_{m} I_{v} \\
& \frac{d E_{m}}{d t}=\beta S_{m} I_{v}-\mu_{2} E_{m}-\sigma E_{m} \\
& \frac{d A_{m}}{d t}=\sigma E_{m}-\mu_{2} A_{m}-\vartheta A_{m} \\
& \frac{d K_{m}}{d t}=\vartheta A_{m}-\mu_{2} K_{m}
\end{aligned}
$$

Dimana:

\begin{tabular}{|c|l|}
\hline$a_{m}$ & Laju Kelahiran \\
\hline$a_{v}$ & Laju Kelahiran \\
\hline$\gamma$ & $\begin{array}{l}\text { Laju populasi manusia yang rentan ke populasi manusia exposed dengan } \\
\text { adanya interaksi populasi nyamuk terinfeksi dengan populasi manusia } \\
\text { rentan }\end{array}$ \\
\hline$\varphi$ & Laju populasi nyamuk dalam masa exposed ke populasi nyamuk terinfeksi \\
\hline$\beta$ & $\begin{array}{l}\text { Laju populasi nyamuk yang rentan ke populasi nyamuk exposed } \\
\text { dengan adanya interaksi populasi nyamuk rentan dengan populasi } \\
\text { manusia terinfeksi }\end{array}$ \\
\hline
\end{tabular}




\begin{tabular}{|c|l|}
\hline$\sigma$ & $\begin{array}{l}\text { Laju populasi manusia dalam masa exposed ke populasi manusia } \\
\text { yang terinfeksi }\end{array}$ \\
\hline$\vartheta$ & Laju populasi manusia yang terinfeksi ke populasi manusia kronis \\
\hline$\mu$ & Laju kematian alami \\
\hline
\end{tabular}

\subsection{Analisis Kestabilan dari Model}

\subsubsection{Titik Kritis dan Eksistensinya}

Titik kritis dari sistem persamaan diferensial yang diperoleh dengan menyelesaikan persamaan-persamaan sebagai berikut:

$$
: \frac{d S_{v}}{d t}=\frac{A_{v}}{\mu_{1}}, \frac{d E_{v}}{d t}=0, \frac{d I_{v}}{d t}=0, \frac{d S_{m}}{d t}=\frac{A_{m}}{\mu_{2}}, \frac{d E_{m}}{d t}=0, \frac{d A_{m}}{d t}=0, \frac{d K_{m}}{d t}=0
$$

Sehingga diperoleh 2 titik kritis, yaitu $T_{1}=\left(\frac{a_{v}}{\mu_{1}}, 0,0, \frac{a_{m}}{\mu_{2}}, 0,0,0\right)$ dan $T_{2}=$ $\left(S_{v}, E_{v}, I_{v}, S_{m}, E_{m}, I_{m}, K_{m}\right)$, dimana:

$$
S_{v}=\frac{a_{v}\left(\mu_{2} \gamma\left(\mu_{1}+\varphi\right)+\beta \varphi \gamma \mu_{1} a_{v}\right)\left(\sigma+\mu_{2}\right)\left(\vartheta+\mu_{2}\right)}{\mu_{1}\left(\mu_{2} \gamma\left(\mu_{1}+\varphi\right)+\beta \varphi \gamma \mu_{1} a_{v}\right)\left(\sigma+\mu_{2}\right)\left(\vartheta+\mu_{2}\right)+\gamma\left(a_{m i} \sigma \varphi \gamma \mu_{1} a_{v}-\mu_{1} \mu_{2}\left(\mu_{1}+\varphi\right)\left(\sigma+\mu_{2}\right)\left(\vartheta+\mu_{2}\right)\right)}
$$

$E_{v}=\left(\begin{array}{c}\frac{\gamma a_{v}\left(a_{m} \sigma \varphi \gamma \mu_{1} a_{v}-\mu_{1} \mu_{2}\left(\mu_{1}+\varphi\right)\left(\sigma+\mu_{2}\right)\left(\vartheta+\mu_{2}\right)\right)}{\mu_{1}^{2}\left(\mu_{2} \gamma\left(\mu_{1}+\varphi\right)+\beta \varphi \gamma a_{v} \mu_{1}\right)\left(\sigma+\mu_{2}\right)\left(\vartheta+\mu_{2}\right)+\varphi \mu_{1}\left(\mu_{2} \gamma\left(\mu_{1}+\varphi\right)+\beta \varphi \gamma a_{v} \mu_{1}\right)\left(\sigma+\mu_{2}\right)\left(\vartheta+\mu_{2}\right)} \\ +\mu_{1} \gamma\left(a_{m} \sigma \varphi \gamma \mu_{1} a_{v}-\mu_{1} \mu_{2}\left(\mu_{1}+\varphi\right)\left(\sigma+\mu_{2}\right)\left(\vartheta+\mu_{2}\right)\right)+\gamma \varphi\left(a_{m} \sigma \varphi \gamma \mu_{1} a_{v}-\mu_{1} \mu_{2}\left(\mu_{1}+\varphi\right)\left(\mu_{2}+\sigma\right)\left(\mu_{2}+\vartheta\right)\right)\end{array}\right)$

$$
I_{v}=\left(\frac{\gamma a_{v} \varphi\left(a_{m} \sigma \varphi \gamma \mu_{1} a_{v}-\mu_{1} \mu_{2}\left(\mu_{1}+\varphi\right)\left(\sigma+\mu_{2}\right)\left(\vartheta+\mu_{2}\right)\right)}{\mu_{1}\left(\begin{array}{l}
\mu_{1}^{2}\left(\mu_{2} \gamma\left(\mu_{1}+\varphi\right)+\beta \varphi \gamma a_{v} \mu_{1}\right)\left(\sigma+\mu_{2}\right)\left(\vartheta+\mu_{2}\right)+\varphi \mu_{1}\left(\mu_{2} \gamma\left(\mu_{1}+\varphi\right)+\beta \varphi \gamma a_{v} \mu_{1}\right)\left(\sigma+\mu_{2}\right)\left(\vartheta+\mu_{2}\right) \\
+\mu_{1} \gamma\left(a_{m} \sigma \varphi \gamma \mu_{1} a_{v}-\mu_{1} \mu_{2}\left(\mu_{1}+\varphi\right)\left(\sigma+\mu_{2}\right)\left(\vartheta+\mu_{2}\right)\right)+\gamma \varphi\left(a_{m} \sigma \varphi \gamma \mu_{1} a_{v}-\mu_{1} \mu_{2}\left(\mu_{1}+\varphi\right)\left(\mu_{2}+\sigma\right)\left(\mu_{2}+\vartheta\right)\right)
\end{array}\right)}\right)
$$

$S_{m}=\left(\begin{array}{l}\frac{a_{m} \mu_{1}\left(\begin{array}{l}\mu_{1}^{2}\left(\mu_{2} \gamma\left(\mu_{1}+\varphi\right)+\beta \varphi \gamma a_{v} \mu_{1}\right)\left(\sigma+\mu_{2}\right)\left(\vartheta+\mu_{2}\right)+\varphi \mu_{1}\left(\mu_{2} \gamma\left(\mu_{1}+\varphi\right)+\beta \varphi \gamma a_{v} \mu_{1}\right)\left(\sigma+\mu_{2}\right)\left(\vartheta+\mu_{2}\right) \\ +\mu_{1} \gamma\left(a_{m} \sigma \varphi \gamma \mu_{1} a_{v}-\mu_{1} \mu_{2}\left(\mu_{1}+\varphi\right)\left(\sigma+\mu_{2}\right)\left(\vartheta+\mu_{2}\right)\right)+\gamma \varphi\left(a_{m} \sigma \varphi \gamma \mu_{1} a_{v}-\mu_{1} \mu_{2}\left(\mu_{1}+\varphi\right)\left(\mu_{2}+\sigma\right)\left(\mu_{2}+\vartheta\right)\right)\end{array}\right)}{\mu_{1} \mu_{2}\left(\begin{array}{l}\mu_{1}^{2}\left(\mu_{2} \gamma\left(\mu_{1}+\varphi\right)+\beta \varphi \gamma a_{v} \mu_{1}\right)\left(\sigma+\mu_{2}\right)\left(\vartheta+\mu_{2}\right)+\varphi \mu_{1}\left(\mu_{2} \gamma\left(\mu_{1}+\varphi\right)+\beta \varphi \gamma a_{v} \mu_{1}\right)\left(\sigma+\mu_{2}\right)\left(\vartheta+\mu_{2}\right) \\ +\mu_{1} \gamma\left(a_{m} \sigma \varphi \gamma \mu_{1} a_{v}-\mu_{1} \mu_{2}\left(\mu_{1}+\varphi\right)\left(\sigma+\mu_{2}\right)\left(\vartheta+\mu_{2}\right)\right)+\gamma \varphi\left(a_{m} \sigma \varphi \gamma \mu_{1} a_{v}-\mu_{1} \mu_{2}\left(\mu_{1}+\varphi\right)\left(\mu_{2}+\sigma\right)\left(\mu_{2}+\vartheta\right)\right)\end{array}\right)} \\ +\gamma a_{v} \varphi \beta\left(a_{m} \sigma \varphi \gamma \mu_{1} a_{v}-\mu_{1} \mu_{2}\left(\mu_{1}+\varphi\right)\left(\sigma+\mu_{2}\right)\left(\vartheta+\mu_{2}\right)\right)\end{array}\right)$

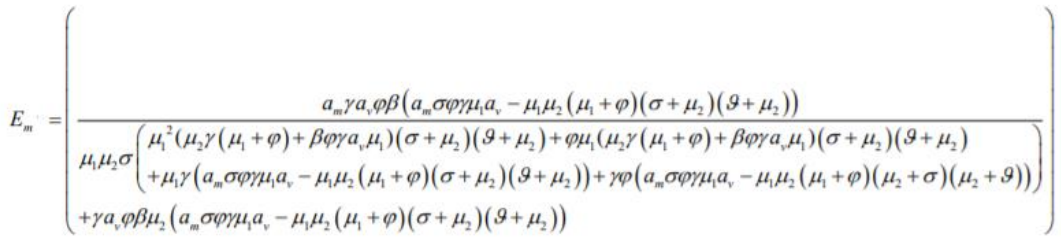

$$
\begin{aligned}
& A_{m}{ }^{\prime}=\frac{\left(a_{m} \sigma \varphi \gamma \mu_{1} a_{v}-\mu_{1} \mu_{2}\left(\mu_{1}+\varphi\right)\left(\mu_{2}+\sigma\right)\left(\mu_{2}+\vartheta\right)\right)}{\left(\mu_{2} \gamma\left(\mu_{1}+\varphi\right)+\beta \varphi \gamma a_{v} \mu_{1}\right)\left(\mu_{2}+\sigma\right)\left(\mu_{2}+\vartheta\right)} \\
& K_{m}{ }^{\prime \prime}=\frac{\vartheta\left(a_{m} \sigma \varphi \gamma \mu_{1} a_{v}-\mu_{1} \mu_{2}\left(\mu_{1}+\varphi\right)\left(\mu_{2}+\sigma\right)\left(\mu_{2}+\vartheta\right)\right)}{\left(\mu_{2}^{2} \gamma\left(\mu_{1}+\varphi\right)+\beta \varphi \gamma a_{v} \mu_{1}\right)\left(\mu_{2}+\sigma\right)\left(\mu_{2}+\vartheta\right)}
\end{aligned}
$$


Titik kritis $T_{1}$ menggambarkan kondisi bebas penyakit, sedangkan titik kritis $T_{2}$ menggambarkan kondisi endemik. Titik kritis pertama dapat dijamin eksistensinya karena $S_{v}=\frac{a_{v}}{\mu_{1}}$ dan $S_{m}=\frac{a_{m}}{\mu_{2}}$ bernilai non negatif. Sedangkan eksistensinya titik kritis endemik penyakit filariasis akan tercapai jika bernilai non negatif. Dapat dijamin eksistensinya dengan syarat $a_{m} a_{v}<\frac{\mu_{2}\left(\mu_{1}+\varphi\right)\left(\mu_{2}+\sigma\right)\left(\mu_{2}+\vartheta\right)}{\sigma \varphi \gamma}, a_{m} a_{v}<\frac{\mu_{2}\left(\mu_{1}+\varphi\right)\left(\mu_{2}+\sigma\right)\left(\mu_{2}+\vartheta\right)}{\sigma \varphi \mu_{1} \gamma}$, $\frac{\mu_{2}\left(\mu_{1}+\varphi\right)\left(\mu_{2}+\sigma\right)\left(\mu_{2}+\vartheta\right)}{\sigma \varphi \mu_{2} \gamma}$

\subsubsection{Kestabilan dari Tititk Kritis}

Kestabilan dari tititk kritis $T_{1}$ dan $T_{2}$ dapat ditentukan melalui tanda negatif dari semua nilai eigen $\lambda$ yang diperoleh dari matriks Jacobi. Matriks Jacobi dari sistem persamaan diferensial yang dievaluasi pada $T_{1}$ memberikan persamaan karakteristik dalam $\lambda$ sebagai berikut:

$$
\left(-\mu_{1}-\lambda\right)\left(-\mu_{1}-\varphi-\lambda\right)\left(-\mu_{1}-\lambda\right)\left(\mu_{2}-\lambda\right)\left(-\mu_{2}-\sigma-\lambda\right)\left(-\mu_{2}-\vartheta-\lambda\left(-\mu_{2}-\lambda\right)=0\right.
$$

Dari persamaan karakteristik di atas diperoleh nilai eigen sebagai berikut:

$$
\begin{aligned}
& -\mu_{1}-\lambda=0 \quad \Rightarrow \lambda_{1}=-\mu_{1} \\
& -\mu_{1}-\varphi-\lambda=0 \Rightarrow \lambda_{2}=-\left(\mu_{1}+\varphi\right) \\
& -\mu_{1}-\lambda=0 \quad \Rightarrow \lambda_{3}=-\mu_{1} \\
& -\mu_{2}-\lambda=0 \quad \Rightarrow \lambda_{4}=-\mu_{2} \\
& -\mu_{2}-\sigma-\lambda=0 \Rightarrow \lambda_{5}=-\left(\mu_{2}+\sigma\right) \\
& -\mu_{2}-\vartheta-\lambda=0 \Rightarrow \lambda_{6}=-\left(\mu_{2}+\vartheta\right) \\
& -\mu_{2}-\lambda=0 \Rightarrow \lambda_{7}=-\mu_{2}
\end{aligned}
$$

Mengingat semua matriks Jacobi dari sistem persamaan diffensial (SPD) yang dievaluasi pada parameter dari $\lambda_{1}, \ldots,, \lambda_{6}$ adalah positif maka di simpulkan bahwa $T_{1}$ adalah stabil dan $T_{2}$ memberikan persamaan karakteristik berderajat 7 dalam $\lambda$ sebagai berikut:

$$
\left(a_{0} \lambda^{7}+a_{1} \lambda^{6}+a_{2} \lambda^{5}+a_{3} \lambda^{4}+a_{4} \lambda^{3}+a_{5} \lambda^{2}+a_{6} \lambda^{1}+a_{7} \lambda^{0}\right)=0
$$

Dimana:

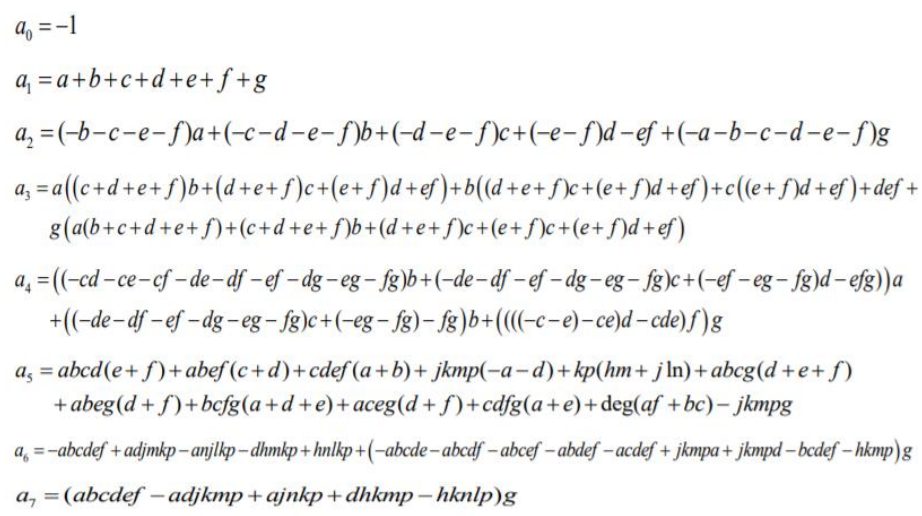


Persamaan karakteristik tersebut didapat koefisien $a_{0}, a_{1}, a_{2}, a_{3}, a_{4}, a_{5}, a_{6}$ dan $a_{7}$ bernilai negatif. Koefisien- koefisien tersebut ditabelkan mengikuti kriteria Routh Hurwitz.

Tabel 1 : Tabel Routh Hurwitz:

\begin{tabular}{|c|c|c|c|c|}
\hline$\lambda^{7}$ & $a_{0}$ & $a_{2}$ & $a_{4}$ & $a_{6}$ \\
\hline$\lambda^{6}$ & $a_{1}$ & $a_{3}$ & $a_{5}$ & $a_{7}$ \\
\hline$\lambda^{5}$ & $b$ & $b_{2}$ & $b_{3}$ & 0 \\
\hline$\lambda^{4}$ & $c_{1}$ & $c_{2}$ & $c_{3}$ & 0 \\
\hline$\lambda^{3}$ & $d_{1}$ & $d_{2}$ & 0 & 0 \\
\hline$\lambda^{2}$ & $e_{1}$ & $e_{2}$ & 0 & 0 \\
\hline$\lambda^{1}$ & $f_{1}$ & 0 & 0 & 0 \\
\hline$\lambda^{0}$ & $g_{1}$ & 0 & 0 & 0 \\
\hline
\end{tabular}

$$
\begin{array}{ll}
b_{1}=\frac{a_{1} a_{2}-a_{0} a_{3}}{a_{1}}=\frac{a_{1} a_{2}+a_{3}}{a_{1}} & \\
b_{1}=\frac{a_{n-1} a_{n-2}-a_{n} a_{n-3}}{a_{n-1}} & c_{1}=\frac{b_{1} a_{n-3}-b_{2} a_{n-1}}{b_{1}} \\
b_{2}=\frac{a_{n-1} a_{n-4}-a_{n} a_{n-5}}{a_{n-1}} & c_{2}=\frac{b_{1} a_{n-5}-b_{3} a_{n-1}}{b_{1}} \\
b_{3}=\frac{a_{n-1} a_{n-6}-a_{n} a_{n-7}}{a_{n-1}} & c_{3}=\frac{b_{1} a_{n-7}-a_{n-1} b_{4}}{b_{1}} \\
d_{1}=\frac{c_{1} b_{2}-b_{1} c_{2}}{c_{1}} &
\end{array}
$$

Titik kritis $T_{2}$ dikatakan stabil jika tidak ada perubahan tanda pada kolom pertama Tabel Routh Hurwitz. Untuk itu perlu diperiksa apakah nilai- nilai dari $a_{1}, b_{1}, c_{1}, d_{1}, e_{1}, f_{1}$ dan $g_{1}$ bernilai negatif. Mengingat $a_{1}<0$ maka, dari persamaan $b_{1}$ sampai $d_{1}, b_{1}<0$ dipenuhi untuk $a_{1} a_{2}+a_{3}$ yang bernilai positif. Syarat yang harus dipenuhi agar $\frac{a_{1} a_{2}+a_{3} 0}{a_{1}}>0$ adalah $X_{1}>Y_{1}$ dengan

$$
\begin{aligned}
X_{1}= & \gamma^{2}\left(\sigma+\varphi+\vartheta+2 \mu_{1}+4 \mu_{2}\right) A M^{2}+\beta^{2}\left(\sigma+\varphi+\vartheta+3 \mu_{1}+3 \mu_{2}\right) I V^{2}+2 \beta \gamma\left(\sigma+\varphi+\vartheta+3 \mu_{1}+4 \mu_{2}\right) A M I V+ \\
& +\sigma^{2} \varphi+\sigma^{2} \vartheta+3 \sigma^{2} \mu_{1}+3 \sigma^{2} \mu_{2}+\sigma \varphi^{2}+2 \sigma \varphi \vartheta+6 \sigma \varphi \mu_{1}+8 \sigma \varphi \mu_{2}+\sigma \vartheta^{2}+6 \sigma \vartheta \mu_{1}+8 \sigma \vartheta \mu_{2}+9 \sigma \mu_{1}^{2}+24 \sigma \mu_{1} \mu_{2}+ \\
& 15 \sigma \mu_{2}^{2}+\varphi^{2} \vartheta+2 \varphi^{2} \mu_{1}+4 \varphi^{2} \mu_{2}+\varphi \vartheta^{2}+6 \varphi \vartheta \mu_{1}+8 \varphi \vartheta \mu_{2}+8 \varphi \mu_{1}^{2}+24 \varphi \mu_{1} \mu_{2}+16 \varphi \mu_{2}^{2}+3 \vartheta^{2} \mu_{1}+3 \vartheta^{2} \mu_{2}+9 \vartheta \mu_{1}^{2}+ \\
& 24 \vartheta \mu_{1} \mu_{2}+16 \vartheta \mu_{2}^{2}+8 \mu_{1}^{3}+36 \mu_{1}^{2} \mu_{2}+48 \mu_{1} \mu_{2}^{2}+20 \mu_{2}^{3}+8 \varphi \vartheta \mu_{2}+8 \varphi \mu_{1}^{2}+24 \varphi \mu_{1} \mu_{2}+16 \varphi \mu_{2}^{2}+3 \vartheta^{2} \mu_{1}+3 \vartheta^{2} \mu_{2}+ \\
& 9 \vartheta \mu_{1}^{2}+24 \vartheta \mu_{1} \mu_{2}+16 \vartheta \mu_{2}^{2}+8 \mu_{1}^{3}+36 \mu_{1}^{2} \mu_{2}+48 \mu_{1} \mu_{2}^{2}+20 \mu_{2}^{3} \\
Y_{1}= & \left(\sigma^{2}+2 \sigma \varphi+2 \sigma \vartheta+6 \sigma \mu_{1}+8 \sigma \mu_{2}+\varphi^{2}+2 \varphi \vartheta+6 \varphi \mu_{1}+8 \varphi \mu_{2}+\vartheta^{2}+6 \vartheta \mu_{1}+8 \vartheta \mu_{2}+24 \mu_{1} \mu_{2}\right) \gamma A M+\beta I V \\
& \left(9 \mu_{1}^{2}+15 \mu_{2}^{2}\right) A M+\left(8 \mu_{1}^{2}+16 \mu_{2}^{2}\right) I V+\left(\beta \gamma^{2}\right) A M^{2} I V+\left(\beta^{2} \gamma\right) A M I V^{2}
\end{aligned}
$$

Syarat tersebut memberikan jaminan bagi $b_{1}<0$. Karena penyebut dari $c_{1}$ yaitu $b_{1}$ sudah dijamin negatif, maka dari persamaan $x_{1}, c_{1}<0$ dipenuhi bila pembilang dari $c_{1}$, yaitu $b_{1} a_{3}-a_{1} b_{2}$ bernilai positif. Yaitu bila $b_{1} a_{3}-a_{1} b_{2}>0$ 
. Mengingat $b_{1}$ dan $a_{3}$ adalah negatif, maka suku pertama persamaan $y_{1}$ adalah positif. Karena $a_{1}<0$ maka persamaan $y_{1}$ terpenuhi bila $b_{2}$ bernilai positif adalah nilai $b_{2}$ akan positif, jika $a_{4}$ adalah positif. Hal tersebut dipenuhi bila $X_{2}-Y_{3}>0$ atau $X_{2}>Y_{3}$ dengan $X_{2}=((-d e-d f-e f-d g-e g-f g) c+(-e g-f g)-f g) b, Y_{3}=Y_{2}+((c+e)+$ $c e) d+c d e$ Hasil tersebut memberikan $c_{1}$ yang bernilai negatif.

$$
d_{1}=\frac{c_{1} b_{2}-b_{1} c_{2}}{c_{1}}
$$

Karena penyebut dari $d_{1}$ yaitu $c_{1}$ yang bernilai negatif, maka dari persamaan $d_{1}=\frac{c b_{2}-b c_{2}}{c_{1}}$ nilai $d_{1}$ ditentukan oleh $c_{1} b_{2}-b_{1} c_{2}$. Nilai $c_{1}<0$ dan $b_{2}>0$ menjadikan suku pertamanya bernilai negatif. Selanjutnya Karena $b_{1}<0$, perlu diperiksa nilai $c_{2}$, karena nilai $b_{3}$ akan positif jika $a_{1} a_{6}+a_{7}$ adalah negatif, sehingga hal tersebut dipenuhi bila $X_{4}>Y_{4}$ dan $X_{5}<Y_{5}$ dengan $X_{4}=$ adjmkp + hnlkp $+j k m p a+j k m p d, X_{5}=$ abcdef + dhkmp, $\quad Y_{4}=-a b c d e f-a n j l k p-d h m k p+(-a b c d e-a b c d f-a b c e f-a b d e f-$ bcdef-hkmp)g, $Y_{5}=$ ajnkp - hknlp - adjkmp, hasil tersebut memberikan $c_{2}$ yang bernilai negative. Karena $b_{1}, c_{1}$ dan $c_{2}$ negatif sedangkan $b_{2}>0$ maka $c_{1} b_{2}-b_{1} c_{2}<0$ sehingga memberikan $d_{1}>0$ yang menunjukkan terjadinya perubahan tanda pada kolom pertama Tabel Routh Hurwitz. Hal ini memberi arti bahwa $T_{2}$ adalah tidak stabil.

\subsection{Simulasi}

Simulasi dimaksud untuk memberikan ilustrasi kondisi tidak stabil dari titik kritis endemk. Untuk nilai-nilai parameter dengan menggunakan nilai variable dan nilai parameter, dimana $S_{v}$ adalah jumlah populasi nyamuk yang rentan, $E_{v}$ adalah jumlah populasi nyamuk yang exposed, $I_{v}$ adalah jumlah populasi nyamuk yang terinfeksi, $S_{m}$ adalah jumlah populasi manusia yang rentan, $E_{m}$ adalah jumlah populasi manusia exposed, $I_{m}$ adalah jumlah populasi manusia yang terinfeksi, dan $K_{m}$ adalah jumlah posisi manusia yang kronis. Dari nilai parameter dan nilai variabel kita dapatkan simulasi pada Tabel 2.

Tabel 2 : Nilai awal untuk tiap sub populasi

\begin{tabular}{|c|l|l|c|}
\hline Variabel & \multicolumn{1}{|c|}{ Deskripsi } & \multicolumn{1}{c|}{ Nilai } & Sumber \\
\hline$S_{v}(0)$ & Populasi nyamuk yang rentan & 9.821 jiwa & $\begin{array}{c}\text { Profil Dinas Kesehatan } \\
2014\end{array}$ \\
\hline$E_{v}(0)$ & Populasi nyamuk yang exposed & 26,90 jiwa & Dibangkitkan \\
\hline$I_{v}(0)$ & Populasi nyamuk terinfeksi & 0,073 jiwa & Dibangkitkan \\
\hline$S_{m}(0)$ & Populasi manusia yang rentan & 2.876 .689 & $\begin{array}{c}\text { Profil Dinas Kesehatan } \\
\end{array}$ \\
\hline$E_{m}(0)$ & Populasi manusia yang exposed & $7.881,33$ jiwa & $\frac{1}{\text { life time }} \times$ Jumlah populasi \\
\hline$A_{m}(0)$ & Populasi manusia terinfeksi & 21,59 jiwa & $\frac{1}{\text { life time }} \times$ Jumlah populasi \\
\hline$K_{m}(0)$ & Populasi manusia yang kronis & 0,059 jiwa & Profil Dinas Kesehatan \\
& & & 2014 \\
\hline
\end{tabular}


Tabel 3 : Nilai Parameter komputasi

\begin{tabular}{|c|c|c|c|c|}
\hline Parameter & Deskripsi & Nilai & Satuan & Sumber \\
\hline$\mu_{1}$ & Laju kematian alami nyamuk & 0,009 & Jiwa/hari & $\begin{array}{c}\text { Skripsi } \\
\text { Endang Susilowati } \\
2013\end{array}$ \\
\hline$\mu_{2}$ & $\begin{array}{l}\text { Laju kematian alami } \\
\text { manusia }\end{array}$ & 0,0031 & Jiwa/hari & $\begin{array}{c}\text { Skripsi } \\
\text { Endang Susilowati } \\
2013\end{array}$ \\
\hline$\gamma$ & $\begin{array}{l}\text { Laju perpindahan } \\
\text { manusia rentan ke } \\
\text { populasi manusia } \\
\text { exposed }\end{array}$ & 0,0071 & Jiwa/hari & $\begin{array}{c}\text { Profil Dinas } \\
\text { Kesehatan } 2014\end{array}$ \\
\hline$\varphi$ & $\begin{array}{l}\text { Laju perpindahan populasi } \\
\text { nyamuk } \\
\text { exposed ke populasi } \\
\text { nyamuk terinfeksi }\end{array}$ & 0,0046 & Jiwa/hari & Asumsi \\
\hline$\vartheta$ & $\begin{array}{l}\text { Laju perpindahan populasi } \\
\text { manusia terinfeksi ke } \\
\text { populasi manusia kronis }\end{array}$ & 0,0039 & Jiwa/hari & $\begin{array}{l}\text { Profil Dinas Kesehatan } \\
2014\end{array}$ \\
\hline$\sigma$ & $\begin{array}{l}\text { Laju perpindahan populasi } \\
\text { manusia } \\
\text { exposed ke populasi } \\
\text { manusia terinfeksi }\end{array}$ & 0,0025 & Jiwa/hari & Asumsi \\
\hline$\beta$ & $\begin{array}{l}\text { Laju perpindahan populasi } \\
\text { nyamuk rentan ke } \\
\text { populasi nyamuk exposed }\end{array}$ & 0,0034 & Jiwa/hari & $\begin{array}{c}\text { Profil Dinas } \\
\text { Kesehatan } 2014\end{array}$ \\
\hline$a_{m}$ & Laju kelahiran manusia & 0,07 & Jiwa/hari & $\begin{array}{c}\text { Profil Dinas Kesehatan } \\
2014\end{array}$ \\
\hline$a_{v}$ & Laju kelahiran nyamuk & 0,136 & Jiwa/hari & $\begin{array}{c}\text { Profil Dinas } \\
\text { Kesehatan } 2014\end{array}$ \\
\hline
\end{tabular}



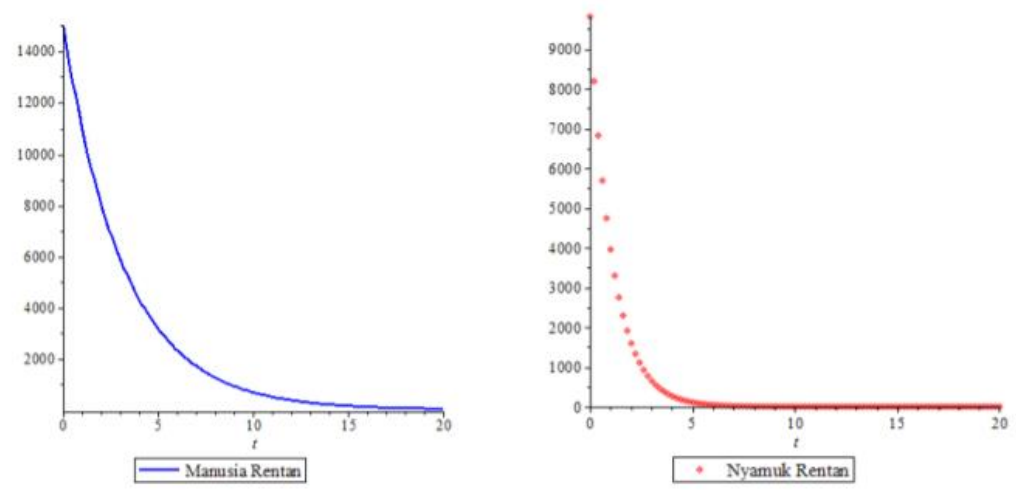

Gambar 2 : Kurva simulasi kondisi bebas penyakit. Nilai variabel $S_{v}(0)=9.821, E_{v}(0)=0$,

$$
I_{v}(0)=0, S_{m}(0)=15.000, E_{m}(0)=0, A_{m}(0)=0, K_{m}(0)=0
$$

Gambar 2 menampilkan simulasi untuk tititk kritis bebas penyakit dengan menggunakan nilai awal $S_{v}(0)=9.821, E_{v}(0)=0, I_{v}(0)=0, S_{m}(0)=15.000, E_{m}(0)=0, A_{m}(0)=0$, $K_{m}(0)=0$ dengan interval waktu 20 bulan. Memperlihatkan bahwa populasi nyamuk rentan dan manusia rentan akan selalu menurun disebabkan adanya interaksi nyamuk rentan dengan manusia yang terinfeksi, dan perpindahan manusia yang rentan menuju ke manusia exposed dengan ada kontak dari nyamuk terinfeksi sehingga dalam kurun waktu 1 bulan akan mengalami penurunan dan akan konstan pada waktu tertentu. Sedangkan gambar 3 menampilkan dinamika keadaan populasi endemik dapat dilihat bagaimana penyebaran penyakit filariasis pada populasi manusia dan nyamuk. Dengan nilai awal 2.876.689 jiwa untuk manusia rentan dan 9.821 jiwa untuk nyamuk rentan, terlihat jumlah manusia rentan dan nyamuk rentan langsung turun pada bulan ke 1 dan akan bernilai tetap dalam arti sudah tidak ada populasi setelah pada bulan ke 1000 untuk populasi manusia rentan dan pada bulan ke 5 untuk populasi nyamuk rentan.

Dengan nilai awal 7.881,33 jiwa dan 26,90 jiwa untuk manusia dan nyamuk exspose, 21,59 jiwa dan 0,073 jiwa untuk manusia dan nyamuk terinfeksi, 0,059 jiwa untuk manusia kronis. Pada kelompok populasi manusia exposed mengalami peningkatan yang cukup signifikan. Terlihat pada gambar 4.4(b) pada bulan 1 sampai bulan ke 3 populasi manusia exposed mengalami peningkatan dan akan turun pada bulan ke 5 . Sedangkan pada populasi nyamuk exposed langsung meningkat pada bulan pertama dan akan turun pada bulan ke 4 . Terlihat bahwa kenaikan populasi exposed lebih besar dari pada populasi terinfeksi. Hal ini dikarenakan banyaknya populasi rentan yang masuk ke populasi exposed. Populasi manusia dan nyamuk exposed mengalami penurunan karena sebagian dari populasi exposed yang sudah siap untuk menginfeksi masuk ke populasi yang terinfeksi dan populasi manusia terinfeksi mengalami penurunan, karena sebagian dari populasi manusia yang sudah parah dan mengalami pembengkakan pada bagian tubuh tertentu akan masuk ke populasi kronis. Pada simulasi terlihat bahwa penyakit filariasis akan terus ada dalam kurun waktu lebih dari 1000 bulan 
kedepan. Dalam grafik terlihat bahwa populasi akan bernilai tetap dalam arti sudah tidak ada populasinya setelah bulan ke 1000 .

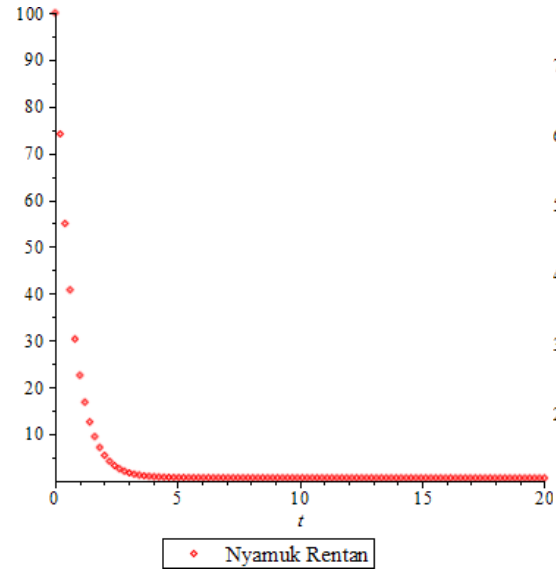

(a)

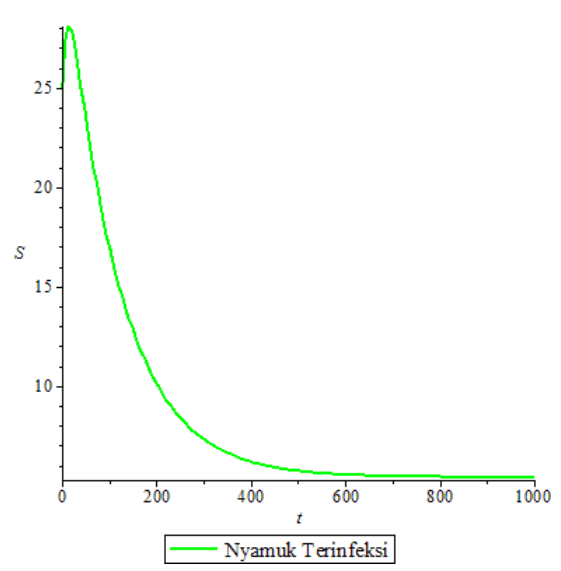

(c)

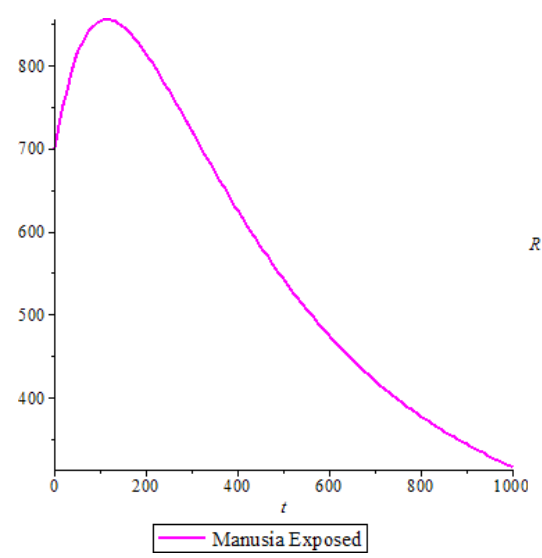

(e)

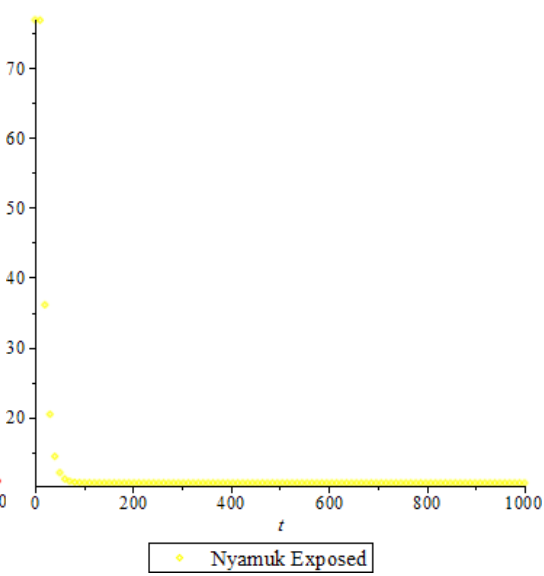

(b)

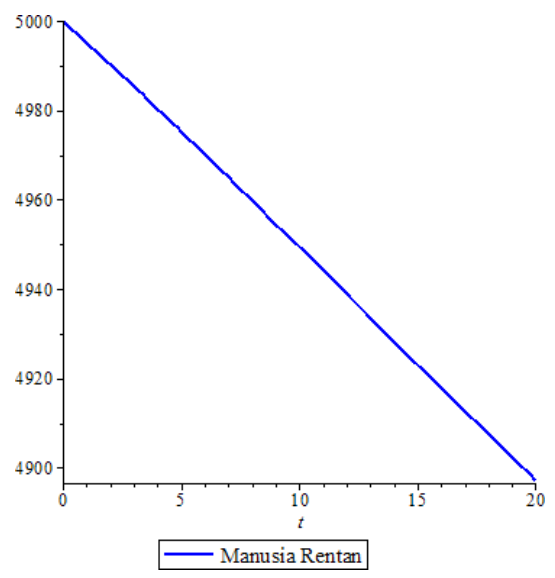

(d)

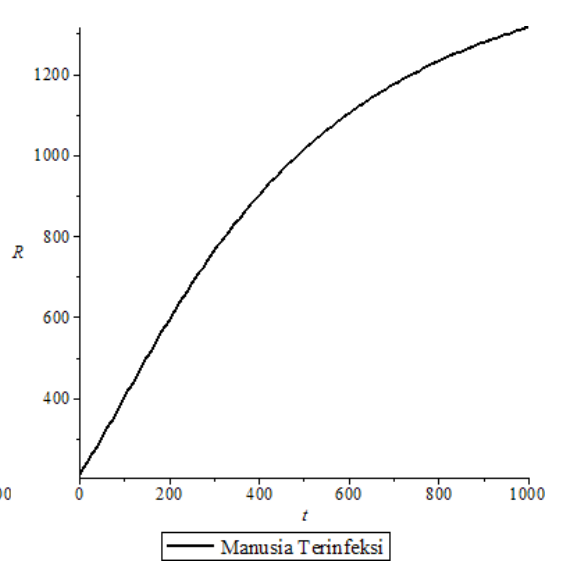

(f) 


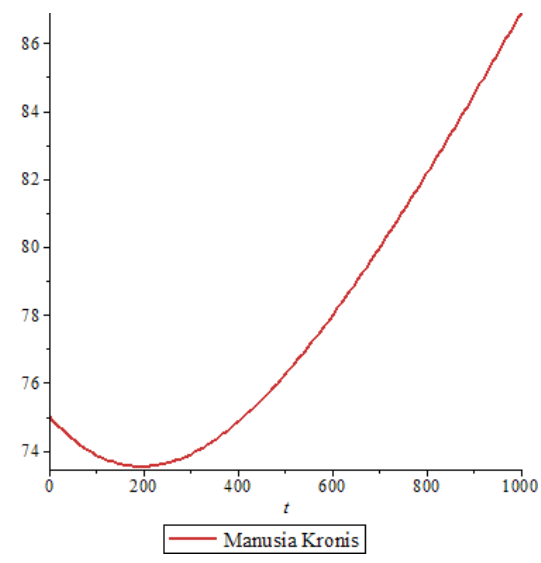

(g)

Gambar 3: Kurva simulasi kondisi endemik penyakit filariasis. Nilai variabel $S_{v}(0)=9.821$, $E_{v}(0)=26,90, I_{v}(0)=0,073, S_{m}(0)=2.876 .689, E_{m}(0)=7.881 .33, A_{m}(0)=21.59, K_{m}(0)=$ 0,059 .

Dari hasil simulasi disimpulkan bahwa penyakit filariasis bersifat menetap sehingga disebut sebagai endemik. Titik kritis yang menggambarkan kondisi endemik yang tidak stabil menunjukkan bahwa dalam kurun waktu yang lama kondisi endemik akan ditinggalkan. Simulasi juga memperlihatkan bahwa perilaku dinamis populasi manusia dan nyamuk memiliki kesamaan yaitu pada populasi manusia dan nyamuk rentan akan selalu menurun yang disebabkan adanya populasi manusia dan nyamuk rentan akan masuk ke populasi exposed. Pada populasi manusia dan nyamuk exposed yang awalnya meningkat, kemudian akan menurun disebabkan karena populasi manusia dan nyamuk exposed sudah siap untuk masuk ke populasi terinfeksi. Pada populasi manusia dan nyamuk terinfeksi yang awalnya meningkat akhirnya menurun disebabkan adanya nyamuk terinfeksi yang menginfeksi manusia rentan sedangkan manusia terinfeksi yang sudah parah akan masuk ke populasi kronis.

\section{KESIMPULAN}

Penelitian ini telah menghasilkan pendekatan model matematika untuk mengetahui perilaku jangka panjang fenomena penularan penyakit filariasis pada populasi manusia. Dari hasil simulasi penyebaran penyakit filariasis yang direpresentasikan oleh model SEAK. Pada model matematika penularan penyakit filariasis diperoleh dua titik kritis, yaitu titik kritis yang menggambarkan kondisi bebas penyakit dan titik kritis yang menggambarkan kondisi endemik. Dalam hal ini menunjukkan bahwa kondisi bebas penyakit bersifat menetap sedangkan kondisi endemik dalam waktu yang lama akan ditinggalkan. Dapat diinterprestasikan pula bahwa kondisi endemik memiliki peluang untuk diatasi. 


\section{DAFTAR PUSTAKA}

[1]. Depkes, R.I, Analisis epidemiologi deskriptif filariasis di Indonesia, 2009, Indonesia.

[2]. Olsder, G.J., Mathematical System Theory, Delft, 2003, The Natherland.

[3]. Suwito, Analisis Kestabilan Titik Kritis Model SEIRS Penyakit Scabies Pada Populasi Hewan dan Model SEIS Pada Populasi Manusia, Universitas Tadulako, 2015, Palu.

[4]. Campbell, S.L., \& Haberman, R, Introduction to Differensial Equitions with Dinamycal System, Princeton University Pree, 2008, New Jersey.

[5]. Subiono, Sistem linear dan Kontrol Optimal, Institut Teknologi Sepuluh Nopember, 2013, Surabaya 